TEME, г. XLII, бр. 4, октобар - децембар 2018, стр. 1373-1387

Оригинални научни рад

DOI: $10.22190 /$ TEME1804373N

Примљено: 27. 1. 2017.

UDK 329(497.11)

Ревидирана верзија: 24. 9. 2018.

Одобрено за штампу: 30. 10. 2018.

\title{
RELIGIOUSNESS OF MEMBERS OF POLITICAL PARTIES IN SERBIA - POLITICAL MANIPULATION OR GENUINE BELIEF?
}

\author{
Ana Nešić ${ }^{1 *}$, Žolt Lazar ${ }^{2}$ \\ ${ }^{1}$ University of Novi Sad, Faculty of Technical Sciences, Novi Sad, Serbia \\ ${ }^{2}$ University of Novi Sad, Faculty of Phylosophy, Novi Sad, Serbia \\ *ana.nesic@uns.ac.rs
}

\begin{abstract}
Transitional changes in economic, political and social contexts have also contributed to the changes within the value framework and religious affiliation. The paper analyzes the results of a survey carried out on the members of political parties concerning their attitudes towards religion and values important in the current social moment in Serbia. For forty years Serbia had been into socialistic system, in which it was not desirable to be religious, so the changes and period of transition that took place largely changed attitudes towards religion. The results indicate an increase in the number of religious people in relation to previous studies, and existence of differences in value judgment among the respondents who identify themselves as religious and those who identify themselves as unbiased and non-religious. Most respondents bind their attitudes to traditional values, not strictly religious, and in behavior, attitudes manifest themselves through religious customs more than beliefs.
\end{abstract}

Key words: religiousness, political orientation, value judgments, attitudes, religion.

\section{РЕЛИГИОЗНОСТ СТРАНАЧКИХ ПРИПАДНИКА - ПОЛИТИЧКА МАНИПУЛАЦИЈА, ИЛИ ИСКРЕНО ВЕРОВАЊЕ?}

\footnotetext{
Апстракт

Транзиционе промене у економском, политичком и друштвеном контексту допринеле су и променама унутар вредносног оквира, као и верске припадности. Скоро четрдесет година Србија је била у социјалистичком систему, у коме није било пожељно бити религиозан, тако да су промене у периоду транзиције, у великој мери допринеле и променама ставова према религији. У раду се анализирају резултати истраживања чији узорак су чинили чланови политичких партија, а предмет истраживања су ставови према религији и доминантним вредностима у тренутном друштвеном моменту у Србији. Резултати указују на повећање броја верујућих људи у односу на претходна истраживања, али и на постојање разлика у
} 
вредностима између религиозних и нерелигиозних испитаника. Већина испитаника везује своје ставове за традиционалне вредности, а не строго религиозне, док се у понашању ставови одражавају више кроз верске обичаје него кроз веровања.

Кључне речи: религиозност, политичка оријентација, систем вредности, ставови, религија.

\section{INTRODUCTION}

Modern life conditions have contributed to a number of changes related to knowledge, behaviour, and opinions of individuals and groups of people. Attitudes towards religion, politics, interpersonal relationships and value systems have also changed. Large amounts of information, new insights, new jobs, products and services have contributed to the change in the place and role of the humans in society. The change that most reflects the end of the twentieth and the beginning of the twenty-first century refers to the role of humans and, as Inglehart says, "humanistic transformation of modernization" (Inglehart \& Welzel, 2005, p. 47), which includes freedom of choice and need for self-expression as one of the key requirements of modern era. Higher standards of living and increasing needs caused by the expansion of markets and changes in the needs of population also changed individual's attitude towards himself/herself. As a result of industrialization the nature has been increasingly taken under control, diminishing to some extent the importance of religion and allowing the dominance of materialist ideology, which essentially led only to the shift of authority from traditionalreligious to secular-rational sources. Political orientation is a complex construct that recognizes the rational, emotional and conative aspects of attitudes towards political reality. Manipulation represents the communication in which the person who manipulates expresses control over other people, most often against their will or interests, and can lead to inequality (Van Dijk, 2006). In political discourse, manipulation is dangerous because it is often not clear that it exists and everything that it carries with.

Changes in Serbia in recent decades related to the social system, and economic and social relations have occurred as a result of many changes in the world; some of them led to improvements, but some to negative social tendencies. Introduction of a multi-party system and development of parliamentarism, political rights and freedom have contributed to the establishment of a new political culture that has still not advanced to the level acceptable to developed countries. The place and role of religion in the extended transitional conditions has been altering along with transitional and political changes.

The essential question which preceded our survey is that if societies become increasingly modernized, do they also become increasingly secularized? Secular worldview represents the height of neutral, objective 
human reason, as opposed to the emotions and irrationality in traditional religious worldviews. With progress and modern development, will eventually all societies will become secular? Thus, the following research questions are significant regarding the topic:

- Do members of political parties in Serbia identify themselves as believers, nonbelievers, or neutral?

- To what extent they express their religious affiliation and beliefs?

- Are there differences in attitudes towards important value-related issues in society as a function of religious feelings?

- Do the values that religiousness provides offer a better picture of party members, than those that provide their real political behavior?

- Is the "use" of religiosity intentional, or are members of political parties providing a better picture of themselves?

\section{RELIGIOUSNESS IN MODERN POLITICS SOCIETY}

Religious feelings seem to be an orientation which is based on views cognitive by nature, attitudes emotional by nature, and other feelings, such as dependence, helplessness, admiration for supernatural being, dynamic views on the need to perform religious rituals, attitudes towards the institutions of specific denomination, as well as specific moral judgments. Religiousness can also be defined as a subjective set of attitudes and system of permanent internal dispositions which includes belief, insights, feelings and behaviours that combine what is the most intimate to the person (Fox, 2018). Traditionally, religiousness is a synthesis of religious consciousness and religious behaviour and association.

In a comparative study of secularization on a global scale, Norris and Inglehart (2011) suggest three dimensions for the measurement of secularization: religious participation, that involves collective religious practices and the erosion of individual religious practices; religious values, that pertain to the goals that people prioritize for their society, community and themselves; and religious beliefs, that refer to the faith in the core beliefs held by different world theologies (Norris \& Inglehart, 2011).

Religiousness can also be observed through more complex concepts, such as Allport and Ross' concept which involves intrinsic and extrinsic religiousness. In intrinsic religiousness, the main motive is inner or interiorized religiousness. Extrinsic religiousness is a more instrumental religiousness and it is based on social needs related to other people, particularly to the need for acceptance, and it is also often in the function of satisfying some other needs, such as social status, power, prestige, role, etc. Allport and Ross explain the two concepts by considering intrinsic religiousness being the one that the person lives, and extrinsic religiousness being the one that the person applies (Allport \& Ross, 1967). 
Compared to the previous period a revitalization of religion occurred, especially if considering only the part related to religious practice and the frequency of religious rites. Blagojevic (2008) believes that "religiousness in Serbia certainly is not an example of mass flight of people from religion and church. Although the most important indicators of conventional religiousness in the Catholic religious-spiritual circle are such that declared religiosity is the most widespread phenomena in them compared to the mixed, Protestant and Orthodox milieu, as far as Serbia is concerned, this distance is quite reduced, so that claims of religiousness and belief in God in Serbia are approaching the situation in Catholic countries (Italy and Portugal) and is significantly higher, not only compared to the Protestant (Denmark and Sweden) and confessionally diverse countries, but also to Orthodox Russia" (Blagojević, 2008, p. 255).

The researchers found that religious beliefs and religiousness remain relatively stable among adults, although certain life events (e.g. divorce, death of a loved one, serious illness) tend to increase the role of religion, and that during his life the average individual does not change his religious attitudes to a greater extent (Cochran, 1988). Obviously, trust in the church is not only an expression of a specific, isolated and variable attitude, but it is largely incorporated into a broader system of values marked mainly by traditionalism, but it cannot be considered in a reductionist manner. A sizeable study of religiousness, often controversial (Shetkat \& Ellison, 1999) conducted among respondents of different generations showed that only about $5 \%$ of the respondents born before the baby boom era (before 1946) claimed to be non-religious, while this number is more than doubled (11\%) among baby boomers. Thus, when regarding respondents born after 1976 (generation Y) 19\% of them do not respect religious traditions. For example, as measured in $1997,14 \%$ of the respondents born in the period from 1965 to 1976 (generation X) consider themselves not identified with religious tradition, which is almost the same result as in 2007. In 1987, half of the respondents (49\%) provided conservative answers, while in 2007, only $30 \%$ of them responded in this way. This trend is recognizable in most societies (Trends in Political Values and Core Attitudes, 2007). When it comes to connection between religiousness and morality- this topic is discussed throughout the centuries, and most of the theorists, like a Hauser and Singer, argued that religion is separable from morality (Hauser \& Singer, 2005).

For example, in American politics, religion plays an important role and often stands out in the public life of both parties. Clifford and Gaskin (2016) argue that candidates emphasize their religiousness in order to influence the increase in the level of perception of their reliability and morale in the wider electoral body at least. So the expression of religiosity serves not only ideological purposes but also a pragmatic attitude towards the electorate (Clifford \& Gaskin, 2016). Many authors believe that religion 
has influence on political attitudes (Duriez et al., 2002), the others believe that political attitudes are only indirectly influenced by religion (Schwartz \& Huysmans, 1995; Schwartz et al., 2014), and in a way that specific theological teachings emphasize the importance of some values, shaping thereby the person's value system as the guidelines in the formation of political attitudes (Van Gyes \& De Witte, 1999), which in turn makes a difference between cultural conservatism versus progressivism. Other authors extend this view by adding economic conservatism versus progressivism. Barnea and Schwartz (1998) imply that politically relevant dimensions may vary by countries, so that specific political context is of crucial importance.

Duriez and associates (2002) think that religion affects political attitudes only indirectly, by its influence on the system values of the believer, and system values can be used as a guideline in shaping political attitudes. The results of the study in Belgium, for 389 psychology students, have shown that value orientations have a greater predictive power on political attitudes rather than religiousness, yet religiousness can provide additional information on the prediction of political attitudes. Measured by Schwarz's value inventory and Deimpler's scale of post-criticism, the results show that values, such as economic conservatism, cultural conservatism, racism and nationalism contribute to the prediction of political attitudes to a certain extent. Every political attitude is associated with a more or less unique combination of religious attitudes and values. For example, economic conservatism is related to power, cultural conservatism is linked to the focus on achievement, security and self-connection, while nationalism is associated with the tendency towards conformism (Duriez et al., 2002).

A study conducted in former Yugoslavia in 1984 showed that the share of traditionally religious people is $10 \%$, which makes a low level of religiousness. Comparing to 1974, when the share of the non-religious (atheists) reached its peak (58\%), in 1984 the share of atheist was significantly lower (38\%), with the increase in the share of respondents classified as "mixed type" (Pantić, 1988).

The rapid recovery of religiousness among young people in the second half of 1980's can be seen as a result of the deepening social crisis, which has particularly affected the young generation, causing high unemployment, lack of perspective and mass anomie. The fact that the role of factors like gender, age, and place of residence is now less important in deciding religiousness than in the past (or have a significantly weaker impact) is only a proof that religion has become, at least at the declarative level, a far more general and publicly acceptable phenomenon than it was previously in the socialist system. Belonging to Orthodoxy in Serbia is more a matter of tradition and identity of the Serbian people than faith.

Theoretically, values and religiousness are considered to be significantly interrelated. On one hand, religion emphasizes the importance of some specific values, while minimizing the importance of some others 
(Rokeach, 1973; Tate \& Miller, 1971). The transmission of religion through socialization, especially within the family, is considered to be the most common value-transmitting way. People with particular value priorities become affiliated with religion or it is religion why they express mechanisms that can positively or negatively reinforce those values (Schwartz \& Huysmans, 1995), or unite values, moral codes, beliefs, rituals, emotions and the community into an integrative whole (Ellison \& George, 1994). The relationship between values and religion should be considered individually because individual features can drive various individuals towards accepting religious beliefs (Beit-Hallahmi \& Argyle, 1997; Fontaine et al., 2000), and values which reflect individual differences (Bilsky \& Schwartz, 1994; Roccass et al., 2002). Understanding that personality traits determine social and political attitudes is not sufficiently scientifically based, and it is certainly not possible to claim that there is a strict indication among them, genetic dispositions must also be considered (Verhulst, Hatemi, \& Martin, 2010).

However, studies show that values are stronger predictors of religiousness than personality traits (Roccas et al., 2002; Rossano, 2008). The relationship between religiousness and values are first studied by Schwartz and Huysmans (1995) on large samples comprising five countries. Their results confirmed almost all the hypotheses that religiousness is positively associated with tradition and compliance, while being associated with safety and benevolence to a lower degree. In addition, religiousness is negatively associated with hedonism, stimulation and self-management, and to a lesser extent with power and universalism in values. Studying the relationship between religion and values was the aim of the research which was carried out using a meta-analysis on a sample from 15 countries based on Schwartz's value model (Schwartz et al., 2014). The results suggest that religious people tend to opt for values that contribute to the preservation of social and personal values related to tradition, compliance, and safety, while avoiding values that contribute to increasing openness to change and autonomy. Also, they are in favour of values that allow self-transcendence (benevolence, but not universalism), and distinguishes not favouring hedonism and values that promote achievement (Saroglou et al., 2004).

A study conducted by Koković and Lazar (2004) on a random sample (except for the place of residence and gender) of 1200 respondents in Serbia, which was aimed at exploring religious distance and religious tolerance of secondary school pupils in Serbia showed that " $60.8 \%$ of respondents in Vojvodina are religious, while $6 \%$ of them are ambivalent towards religion. One-third of respondents are not religious, but consider themselves tolerant towards those who believe, and even join religious ceremonies and customs, although personally it lacks any particular religious significance for them. The lowest share is that of opponents of any religion (1\%)" (Koković \& Lazar, 2004: 264). 


\section{RESEARCH METHODS}

\section{Research Objective}

The aim of the research is to identify the attitude of the surveyed members of different parties in Serbia towards religion, i.e. are they believers, non-believers, or neutral, and to determine whether there are differences between the respondents' different religious determinations in relation to the value judgments on the following personal and universal issues: abortion, a national system of health care, sexual education for children, influential unions, same-sex marriage, restricting the employment of ethnic minorities, reducing the functions of the welfare state, and death penalty.

\section{Research Instrument}

The research was conducted using a questionnaire conceived for the occasion - in the form of Likert's type scale of attitudes. The questionnaire consisted of general demographic questions about gender, age, education level, marital and economic status, workplace, religious denomination and party membership, and a scale of attitudes related to attitudes towards religion, and expressing universal and personal values.

\section{Research Sample}

The sample consisted of 159 respondents, with 102 males and 57 females. Regarding the age of respondents, $11.3 \%$ of them were aged 15$24,31.4 \%$ of them $25-34,27.7 \%$ of them $35-44,8,8 \%$ of them $45-54$, while $3.8 \%$ were over 68 . The share of Ethnicity was as follows: $79.2 \%$ Serbs, $4.4 \%$ Hungarians, 3.1\% Montenegrins, $1.9 \%$ Yugoslavs, while $6.9 \%$ of them identified themselves as "other". The respondents' level of education was as follows: $52.8 \%$ of them held university degree, $10.7 \%$ higher education, $35.8 \%$ secondary education, $0.6 \%$ vocational school. $69.2 \%$ of the respondents identified themselves as employed, $15.7 \%$ as dependent persons, $4.4 \%$ were retired and $10.7 \%$ currently unemployed.

The respondents were activists of nine political parties. For a more accurate statistical analysis the parties were classified into three groups based on their orientations: right-wing, left-wing and centre-oriented. Criteria of this division are based on ideological orientation and also on national identification, i.e. the importance of the national factor in deciding the policy. The reasons for the selection of this sample are reflected in the importance and role of the members of political parties in our society. Taking into account the power and influence that the members of the parties have in their society, their attitudes contribute to the illumination of the behavior of the wider community. 


\section{RESEARCH RESULTS}

The respondents' confessional affiliation is given in Table 1 .

Table 1 Respondents' confessional affiliation

\begin{tabular}{|c|c|c|c|c|c|c|c|c|}
\hline $\begin{array}{c}\text { Confessional } \\
\text { affiliation }\end{array}$ & Orthodox & Catholic & $\begin{array}{c}\text { Slovak } \\
\text { evangelical }\end{array}$ & Judaist & $\begin{array}{l}\text { Lutheran } \\
\text { protestant }\end{array}$ & Atheist & $\begin{array}{c}\text { Non- } \\
\text { believer }\end{array}$ & Other \\
\hline $\begin{array}{c}\text { Percentage } \\
(\%)\end{array}$ & 76.1 & 5 & 4.4 & 0.6 & 0.6 & 7.5 & 3.8 & 1.9 \\
\hline
\end{tabular}

In cumulative percentages, $86.8 \%$ of the respondents in our study identify themselves as believers of some denomination.

The respondents' personal attitudes towards religion are presented in Table 2 in percentages.

Table 2 Respondents' personal attitude towards religion

\begin{tabular}{lc}
\hline Respondents' personal feelings towards religion & Percentage (\%) \\
\hline Believers observing all practices required by their faith & 29.3 \\
Believers not accepting all elements of their faith & 19.5 \\
Believers accepting all that their faith teaches & 18.2 \\
Non believers respecting the religious beliefs of others & 17.0 \\
Non believers observing religious customs & 9.4 \\
Not belonging to any faith, but believing in God & 4.4 \\
Non believers and not interested in religion & 3.8 \\
Not sure if they are religious or not & 2.5 \\
Opponents of any religion & 1.3 \\
\hline
\end{tabular}

Source: Authors

When summing the determinants: I am a believer and accept everything that my religion teaches (18.2\%), I am a believer and observe all practices required by my faith (29.3\%), and I am a believer but I do not accept everything that my faith requires $(19.5 \%), 67 \%$ of respondents opted for these answers. A significantly higher percentage of respondents preferred confessional affiliation over personal feelings towards religion, which may indicate the need for belonging to collectives such as the Orthodox, Catholics, Judaist or other entities. Seeing the attitude towards religion as a makeshift scale of polarities, two respondents claimed to be opponents of any religion, while 29 of them responded that they are believers and accept everything their faith teaches, and four respondents said they were not sure whether they are religious or not.

For the needs of our research, we examined the relationship of the respondents to religiosity with a Likert scale type with 3 levels: 1 - I am religious, 2 - I am neutral 3 - I am not religious. Since we are not having a normal distribution, we observed Spearman correlation coefficient. If we look at the impact of religiosity on attitudes toward the values, we get the 
positive correlations that are significant for the following items from a set of values: - It is not good to change many things at once; - The traditional family must be preserved; - The state needs the most one courageous leader; A woman should take care of the family, a man for the community; Children need to learn the obedience and respect for authority; - I would not give my vote for the women candidate in a presidential election which values can be considered as traditional values.

Positive correlations were obtained if we observe coding of variable with three levels: 1 - strongly agree, 2 - partially agree and 3 - I do not agree and items taken from a set of values that are encoded in the same way, the direction of the correlation is obtained as expected. According to Cohen's guidelines for determining the strength of the relationship (Cohen, 1988), all significant correlations have little strength, except the item "The traditional family must be preserved", where we have a very strong correlation. The coefficient of determination, which we used to determine how much of the variance of one variable is explained by the variance of another variable, gave the following results:

- It is not good to change many things at once.

- The traditional family must be preserved.

- The state needs the most one courageous leader. $2.5 \%$

- A woman should take care of the family, a man for the community

- Children need to learn the obedience and respect for authority.....

- I would not give my vote for the women candidate in a presidential election. $3.5 \%$

Positive correlations exist for the following items from a set of values:

- The traditional family must be preserved.

- A woman should take care of the family, a man for the community.

- I would not give my vote for the women candidate in a presidential election.

The results indicate a weak strength correlation and all correlations are negative, which is understandable if we take into account the coding variables. The political category is coded "left to right", ie. the number 1 the left wing, 2 - center and 3 - right wing. If we observe values of 1,2 and 3 as "entirely", "partially" or "no", question that should appear in the questionnaire is "To what extent are you politically left-wing oriented?"

The coefficient of determination for the listed items is:

- The traditional family must be preserved.

- A woman should take care of the family, a man for the community

- I would not give my vote for the women candidate in a presidential election 
In the analysis we chose the coefficient of determination, which measures variables with more precise meanings, for our nature of data. The determination coefficients explain how the given independent variable has a share in the explanation of variation of independent variables.

Table 3 Chi-Square Tests

\begin{tabular}{lccc}
\hline & Value & Df & Asymp. Sig. (2-sided) \\
\hline Pearson Chi-Square & $19.745^{\text {a }}$ & 4 & .001 \\
Likelihood Ratio & 19.702 & 4 & .001 \\
Linear-by-Linear Association & 11.967 & 1 & .001 \\
N of Valid Cases & 159 & & \\
\hline \multicolumn{3}{c}{ a -0 cells (0.0\%) have expected count less than 5. } \\
The minimum expected count is 6.05. \\
Source: Authors
\end{tabular}

The assumption of minimum expected cell frequency was fulfilled (zerocell with an expected frequency of less than 5). All frequencies are higher than 6. Pearson Chi-Square was 19.745 with a significance of 0.001 - there is a statistically significant relationship between religious categories and political categories.

Table 4 Political categories and religious categories - Crosstabulation

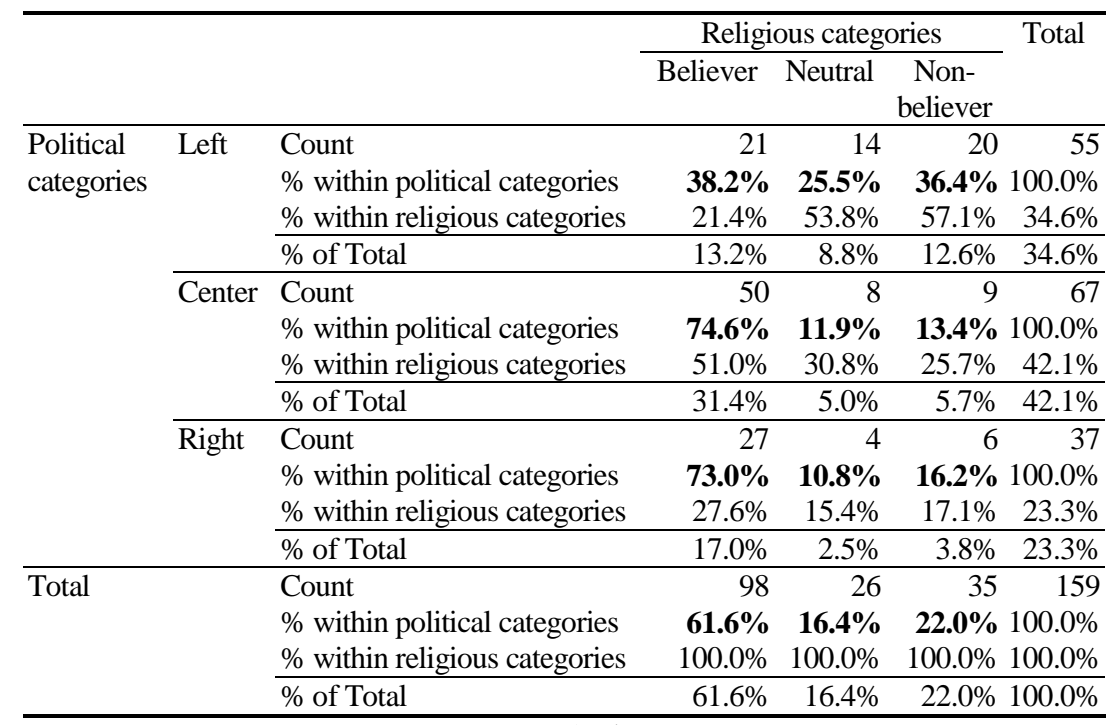

Source: Authors

From the table above, which shows a cross-tabulation distribution of respondents according to political and religious categories, we can read the data on the percentage of believers in every political category, and vice versa, 
as well as the overall percentages. For example, among the members of leftorientated political parties $38 \%$ are believers, $26 \%$ are neutral and $36 \%$ are non-believers. Members of political parties belonging to the center, $75 \%$ of them are believers, $12 \%$ are neutral and $13 \%$ are non-believers, while the members of right-oriented political parties have the following distribution: $73 \%$ are believers, $11 \%$ are neutral and $16 \%$ are non-believers. As for the entire sample, $62 \%$ of our respondents were believers, $16 \%$ were neutral, while $22 \%$ were non-believers.

For the diagnosis of magnitude of the effects, as shown in Table 5, we used the Cramer's indicator.

Table 5 Cramer's $V$

\begin{tabular}{llcc}
\hline & & Value & Approx. Sig. \\
\hline Nominal by Nominal & Phi & .352 & .001 \\
& Cramer's V & $\mathbf{. 2 4 9}$ & $\mathbf{. 0 0 1}$ \\
N of Valid Cases & & 159 & \\
\hline \multicolumn{3}{c}{ Source: Authors }
\end{tabular}

In our case, $\mathrm{V}=0.249(\mathrm{p}=0.001)$ - it is a medium impact, that is, there is a medium strong correlation between religious categories and political categories of respondents.

\section{DISCUSSION}

The analysis of the research results indicates a statistically significant difference in the acceptance of certain values in relation to religious commitment expressed through three levels: believer, non-believer and neutral.

For the claim "A woman should take care of the family, a man for the community", there is a statistically significant difference between the two groups: believer - non-believer. Analysis of the results shows the following: for the claim "The traditional family must be preserved" - there is a statistically significant difference between the following groups: leftoriented - center and left-oriented - right-oriented groups.

In the statement, "I would not give my vote for the women candidate in a presidential election" there is a statistically significant difference between the following groups: left wing - right wing.

When it comes to overall results, Pearson Chi-Square (chi-square) was 19.745 , with a significance of 0.001 , indicating that there is a statistically significant relationship between religious categories and political categories, which was de facto the subject of our research. Cramer's indicator shows that there was a medium strong correlation between the studied categories.

As indicated by the difference between believers, non-believers and neutral, believers are more consistent in their values, although the values 
they stand for do not always contribute to progress. Since subjects of this study were the members of different parties, a number of questions were opened such as the role of religiousness in political behaviour, relations between values and political behaviour, possible differences between respondents and their political affiliations, etc.

Similarly, a very high percentage of respondents declared themselves to be believers in the group of right and centrally oriented parties. As the results have shown, traditional values, characteristic for religion, dominate the majority of the existing parties in Serbia. This raises the question of how the change occurs in the society of once non-religious-traditionalists and now religious traditionalists who hold political activities, and that question is really interesting. The results of the research in neighboring Croatia showed that religiosity in post-socialism are a good predictor of value orientations; it can help foreseeing conservatism and authoritarianism, but not nationalism. The reason why nationalism can not be anticipated is that the level of nationalism increases along with religiousness, while the level of other values remained the same or decreased (Sekulić \& Šporer, 2006).

Radical theory notions that exalt values such as democracy, freedom, equality, inclusion, and justice may not necessarily be best pursued within an exclusively immanent secular framework, and in the contrary, the secular may well be a potential site of isolation, domination, violence and exclusion (Mavelli \& Petito, 2012). The question can also be raised about whether the religiousness of the members of the parties is true, or whether it is a matter of deliberately choosing religiousness as a desirable behavior in contemporary political conditions. Is it just an attempt to regain the long-lost confidence in politicians in Serbia, through personal promotion in which they represent themselves as believing people? We must know and pay attention to what are the cultural and historical specificities of the population in which we are researching and examining the religion.

\section{CONCLUSION}

The research results have failed to show the expected differences in attitudes towards religion and value frameworks. The insufficient level of differentiation between the parties also points to the inadequate ideological and political identification of parties, as well as to the political culture of politicians, which is underdeveloped.

The study also showed some disadvantages. The first is reflected in the small and insufficiently systematized sample: over half of the respondents held university degree and were between 25 and 34 years old, which could clearly influence the results. It was very difficult to conduct a research with party activists who showed a clear sense of insecurity, lack of control and need for anonymity on issues that were neither provocative nor required investing a significant mental or ethical effort. 
Religions are very different and have a different relationship with politics depending on the context in which we are conducting our research. The traditional ways in which we understand the relationship between religion and politics as distinct, has little resonance where notions of separated public and private spheres do not exist and where religion is an accepted part of communal life.

Religiousness and beliefs are changing in relations of privatization and subjectivization of traditional values such as goodness, beauty, hope, and the like, which contributed to the increasing risk for these values to be manipulated. On the other hand, many forms of religious ideologies are recreated and revived (Havelka, 2012). In transitional conditions, religiousness in Serbia has not been revitalized at a merely declarative level. There are many examples of young people perceiving religion as a value that cannot be found in the aggressive and competitive business world. Maybe authors from Croatia have right when they point out that "overstating the elements of the politicization of religion and the religionization of politics in post-communist times diverts attention away from other aspects of actual and controversial social processes“ (Marinović, Jerolimov \& Zrinscak, 2006, p. 288).

Since the research was carried out on members of political parties, the division into believer, non-believer and neutral did not show enough precise results. Perhaps, it was possible to take into account the distinction between institutional believers and those who are spiritualy-based, as suggested by Nicolet and Tresch (2009). The changes that have emerged pointed out consecutive to the dual nature of religiosity, which consists of an institutional and spiritual dimension. The institutional dimension depicts the attachment to the church, mostly the affiliation of a particular church, while the spiritual dimension deals with religious beliefs. Their research showed two results. The first one points to a decrease in the number of religious people, and at the same time, the second one shows that non-believing respondents and those who have the spiritual dimension of religiosity are much more open towards cultural liberalism, than the followers of institutionalized forms of religiousness (Nicolet \& Tresch, 2009).

The extent to which it is a passing trend or permanent value cannot be decided without a longitudinal study. The increasing instability and insecurity greatly contributes to the affirmation of religious orientations in Serbia. Yet, the percentage that indicates an increase in positive attitude towards religion is small and insignificantly affects political behaviour.

\section{REFERENCES}

Allport, G., \& Ross, J. (1967). Personal religious orientation and prejudice. Journal of Personality and Social Psychology, 5 (4), 432-443.

Barnea, F., \& Schwrtz, S. (1998). Values and voting. Political Psychology, 19 (1), 17-40.

Beit-Hallahmi, B., \& Argyle, M. (1997). The Psychology of Religious Behaviour, Belief and Experience. London: Routledge. 
Bilsky, W., \& Schwartz, S. (1994). Values and personality. European Journal of Personality, 8, 163-181.

Blagojević, M. (2008). Religiozna Evropa, Rusija i Srbija: juče i danas. [Religious Europe, Russia and Serbia: yesterday and today]. Filozofija i društvo, 19 (3), 235-257.

Clifford, S., \& Gaskin, B. (2016). Trust Me, I Believe in God. American Politics Research, 44 (6), 1066-1097.

Cochran, J. (1988). The effect of religiosity on secular and ascetic deviance. Sociological Focus, 21 (4), 293-306.

Cohen, J.W. (1988). Statistical power analysis for the behavioral sciences. New Jersey: Lawrence Erlbaum Associates Publishers.

Duriez, B. et al. (2002). The importance of religiosity and values in predicting political attitudes: evidence for the continuing importance of religiosity in Flandrs. Mental health, Religion \& Culture, 5 (1), 35-54.

Ellison, C., \& George, L. (1994). Religious involvement, social ties, and social support in a Southeastern community. Journal for the Scientific Study of Religion, 33 (1), 46-61.

Fontaine, J., et al. (2000). Tell me what you belive and I'll tel you what you want. Empirical evidence for discriminating value patterns of five types of religiosity. The International Journal for the Psychology of Religion, 10 (2), 65-84.

Fox, J. (2018). An Introduction to Religion and Politics: Theory and Practice. London: Routledge.

Havelka, M. (2012). Elimination' of Magic (Entzauberung) versus sekularizace?! Sociológia, 44 (5), 564-578

Hauser, M., \& Singer, P. (2005). Morality without Religion. Free Inquiry-Buffalo Then Amherst, 26 (1), 18-19.

Inglehart, R., \& Welzel, C. (2005). Modernization, Cultural Change and Democracy: The Human Development Sequence. New York: Cambridge University Press.

Koković, D. \& Lazar, Ž. (2004). Društvena tranzicija i promene u sistemu vrednosti: primer Vojvodine. [Social transition and changes in the value system: the example of Vojvodina]. Sociološki pregled, 38 (1-2), 249-265.

Mavelli, L., \& Petito, F. (2012). The postsecular in international relations: an overview. Review of International Studies, 38 (5), 931-942.

Marinovic Jerolimov, D. \& Zrinscak, S. (2006). Religion Within and Beyond Borders: The Case of Croatia. Social Compass, 53 (2), 279-290.

Nicolet, S., \& Tresch, A. (2009). Changing Religiosity, Changing Politics? The Influence of "Belonging" and "Believing" on Political Attitudes in Switzerland. Politics and Religion, 2, 76-99.

Norris, P., \& Inglehart, R. (2011). Sacred and Secular: Religion and Politics Worldwide. Cambridge University Press.

Pantic, D. (1988). Klasična i svetovna religioznost. Beograd: Centar za politikološka i javnomnenjska istraživanja.

Roccas, S., et al. (2002). The big five personality factors and personal values. Personality and Social Psychology Bulletin, 28 (6), 789-801.

Rokeach, M. (1973). The nature of human values. New York: Free Press.

Rossano, M. (2008). The Moral Faculty: Does Religion Promote "Moral Expertise"? International Journal for the Psychology of Religion, 18 (3), 169-194.

Saraglou, V., et al. (2004). Values and religiosity: a meta-analysis of studies using Schwartz's model. Personality and Individual Differences, 37 (4), 721-734.

Shetkat, D., \& Ellison, C. (1999). Recent Development and Current Controversies in The Sociology of Religion. Annual Review Sociology, 25, 363-394.

Schwartz, S., \& Huismans, S. (1995). Value priorities and religiosity in four Western religions. Social Psychology Quarterly, 58, 88-107. 
Schwartz, S., Caprara, G., Vecchione, M., Bain, P., Bianchi, G., Caprara, M., Cieciuch, J., Kirmanoglu, H., Baslevent, C., Lönnqvist, J., Mamali, C., Manzi, J., Pavlopoulos, V., Posnova, \& T., Schoen, H. (2014). Basic Personal Values Underlie and Give Coherence to Political Values: A Cross National Study in 15 Countries. Political Behavior, 36 (4), 899-930.

Sekulić, D. \& Šporer, Ž. (2006). Religioznost kao prediktor vrijednosnih orijentacija. [Religiousness as a predictor of value orientations]. Revija za sociologiju, 37(1-2), 1-19.

Tate, D. \& Miller, R. (1971). Differences in value systems of persons with varning religious orientations. Journal for the Scientific Study of Religion, 10, 357-365.

Trend in Political Values and core Attitudes: 1987-2007. (2007). Political Landscape more favorable to Democrats. Pew Research Center for the People \& the Press.

Van Dijk, T. (2006). Discourse and Manipulation. Discourse and Society, 17(2), 359-383.

Van Gyes, G. \& Dewitte, H. (1999). Conservatism and values: A confrontation of Middendorp with Schwartz and Triandis. In: Dewitte \& Scheepers (Eds.) Ideology in the Low Countries. Trends, models and lacunae. Van Gorcum: Assen.

Verhulst, B., Hatemi, P. \& Martin, N. (2010). The nature of the relationship between personality traits and political attitudes. Personality and Individual Difference, 49, 306 - 316.

\title{
РЕЛИГИОЗНОСТ СТРАНАЧКИХ ПРИПАДНИКА - ПОЛИТИЧКА МАНИПУЛАЦИЈА, ИЛИ ИСКРЕНО ВЕРОВАЫЕ?
}

\author{
Ана Нешић ${ }^{1}$, Жолт Лазар ${ }^{2}$ \\ ${ }^{1}$ Универзитет у Новом Саду, Факултет техничких наука, Нови Сад, Србија \\ ${ }^{2}$ Универзитет у Новом Саду, Филозофски факултет, Нови Сад, Србија
}

\section{Резиме}

Религије данас имају различите и другачије односе са политиком, у зависности од контекста у ком вршимо истраживања. Традиционални начини на који схватамо однос религије и политике има мало резонанције, када не постоје јасно одвојени појмови јавне и приватне сфере и где је религија (прихватљив) део заједничког живота. Религиозност и уверења се мењају, са једне стране, у односима приватизације, а са друге стране - субјективизације традиционалних вредности као што су доброта, лепота, нада и слично, што је све допринело повећању ризика да се овим вредностима и лакше манипулише. Истовремено, сагледавамо да се многи облици и обрасци верских идеологија поново обнављају и оживљавају. У транзиционим условима, религиозност у Србији није ревитализирана на само декларативном нивоу. Постоји много примера младих који схватају религију као вредност која се не може наћи у агресивном и конкурентном пословном свету. У оваквом контексту, можда се и може уочити да пренаглашавање елемената политизације религије и религизације политике у посткомунистичком времену скреће пажњу од других аспеката стварних и контроверзних друштвених процеса. Све већа нестабилност и несигурност доприносе и афирмацији верских оријентација у Србији. Ипак, у нашем истраживању, проценат који указује на повећање позитивног односа према религији је мали и незнатан као ефекат утицаја на политичко понашање. 